\title{
What Is an Information Agent? Looking for a New Approach to the Subject of Information Processes
}

\author{
Remigiusz Sapa \\ ORCID 0000-0002-8351-524X \\ Institute of Information Studies \\ Faculty of Management and Social Communication \\ Jagiellonian University in Kraków, Poland
}

\begin{abstract}
Purpose/Thesis: The article opens new research opportunities by going beyond the concept of the information user and contributing to the development of a research paradigm based on the idea of information agency. It proposes a theoretical framework for a new way of thinking about the subject of information processes.

Approach/Methods: This conceptual article is based on theoretical considerations and synthetic, critical analyses of the concept of the information user alongside other ideas underlying the approach proposed here.

Results and conclusions: The article establishes a theoretical framework for thinking about the information agent. The information agent is seen as a dynamic, heterogeneous, multifaced and inseparable system gaining agency in specific situations and losing it in others.

Originality/Value: The article presents the original concept of an information agent together with initial suggestions regarding how to apply it to, and make it operable in, empirical research.
\end{abstract}

\section{Keywords}

Information agency. Information agent. Information user. Methodology. Subject of information processes. Theory of information research.

Received: 12 February 2020. Reviewed: 3 April 2020. Accepted: 28 April 2020.

\section{Introduction}

The article opens new research opportunities by going beyond the concept of the information user, which is deeply entrenched in information science, and contributing to the development of a research paradigm based on the idea of information agency. The specific goal is to establish a theoretical framework for a new way of thinking about the subject of information processes - the information agent. The focus is on its ontological and methodological aspects, as well as on the conditions for gaining or losing information agency. This framework will be useful for designing new empirical research and for guiding interpretation of their results.

Even though according to Dervin "we are suffering ... from changing and competing conceptual frameworks" (Dervin, 2003b), this does not apply to entities interacting with 
information. Although their behavior has been widely studied, these entities have seldom themselves been an object of focused ontological considerations. The concept of the information user, as developed in information science, remains opaque on the empirical level (Julien et al., 2018). Such a user seems to be rather a reified abstract, an automatic consequence of various a priori beliefs and assumptions not always consciously accepted, but, as Julien reminds us,

(...) we need to be mindful of the conceptual parameters we establish by our notions of users and the implications of those parameters (Julien, 1999, 206).

The article will establish a theoretical framework in following steps. Firstly, a brief overview of the development of the concept of the information user will be presented. Secondly, the basic assumptions for the proposed framework will be formulated and a few related notions will be introduced; then the concept of the information agent will be presented. Finally, the key methodological recommendations implied by this concept will be suggested.

\section{Background}

Although the entity interacting with information seems to be at the center of the so-called user studies in information science, they do not in fact focus on the user itself, but rather on its internal interactions (cognitive, affective) or external activities (behaviors) and on its features, as revealed in relations with information, information channels or systems. Some concepts of the user are implicit in information behavior theories (including models) and research as well as in investigations and reflections on information needs, barriers, culture, literacy and education and on personal information management or on the use of information systems. However, according to Julien et al. (2018), since the user-turn in information science, only a few publications have directly engaged with the way the user is (may be) understood. A few significant studies (Booth, 2008; Day, 2011; Fleming-May, 2014; Julien, 1999; McKechnie et al., 2006; Miksa, 2009; Olsson, 2009; Tabak, 2014; Talja, 1997) were synthesized by Julien et al. (2018). However, it is still worth briefly discussing those selected publications (more and less directly associated with the field of information science) as they have shaped the concept of the information agent proposed here.

Studies of sense-making, particularly Dervin's (1999), have been a source of inspiration for this article. Firstly, although Dervin defines the user ("human subject") as a human being with all human attributes, she argues that the focus should be on

(...) both the inner and outer worlds of human beings and the ultimate impossibility of separating them (Dervin, 1999, 730).

Secondly, noticing the tension between static and dynamic views of the human subject, between focusing on its structure or its transformations, Dervin rejects this a priori binary, recognizing that both aspects may manifest themselves in reality, because

(...) humans and their worlds are constantly evolving and becoming, sometimes decentered, sometimes centered, sometimes fluid, sometimes rigid (Dervin, 1999, 731). 
She makes this variability (changing, becoming) the main object of interest (Dervin, 1999, 732). Thirdly, she believes

(...) that it is not necessary to privilege either realism-based or interpretative-based methodologies (Dervin, 1999, 732).

People are guided by theories - "interpretive bridges over a gappy reality" (Dervin, 1999, 730) - created by them on the basis of facts and figures; however, they are also guided by illusions, dreams, feelings, etc., and thus their world is comprises of both real beings and constructs (Dervin, 1999, 740).

In 2011, Day proclaimed the death of the user - it

(...) refers to the end of ego psychology as the foundation for understanding human beings in LIS research and also to the end of ego psychology's understanding of objects as subordinate to personal will and representation (Day, 2011, 78-79).

Although he does not relinquish the vision of a human user, he proposes a new, inspiring approach to its relationships with information. In his opinion, not only the user but also information is "inscribed (...) within nets of social norms and cultural forms" (Day, 2011, 78). Referring to the concept of affordances, understood as "forms that allow something to be expressed and emerge in certain ways" (Day, 2011, 80), as an alternative to mechanistic causality, he argues for

\footnotetext{
the importance of viewing subjects and meaningful objects as co-determined by social, cultural and physical affordances and co-emergent out of those relationships through expressive powers mediated by mutual affects (Day, 2011, 78).
}

Tabak (2014) based his thought-provoking study on actor-network theory (ANT). He indicates the key opportunities ANT provides for information behavior research and for developing an alternative to the so-called user-centered approach. These opportunities arise from assigning agency not only to people but to other entities as well, emphasizing the heterogeneity of entities interacting with information and dynamic relationships between their components, reducing the tension between the user and the context of their behavior as well as rejecting the dichotomy between the individual and the social, or between the subject and the object in information processes. It is necessary to stress that the understanding of the information agent presented below has been influenced by ANT to an even greater degree, following the direction of other publications (Abriszewski, 2008; Callon, 1987; Latour, 1996; Law, 1992; Law \& Hassard, 1999).

Furthermore, Floridi's concept of identity and his interpretation of changes in technology is crucial for this study. Firstly, Floridi recognizes beings (also people) as "constituted by interacting and coordinated components" (Floridi, 2014, 66) and proposes a concept of "information body", which describes the identity of a particular human as composed of all the pieces of information about them, and human beings as functioning through such information and exist even after their organic death (Öhman \& Floridi, 2017). According to Floridi (2014), the so-called third-order technology now operates independently of humans, communicating and performing information transactions without their direct participation. The upcoming 4th revolution will result in 
connecting anything to anything (...), not just humans to humans (...)

(...) for the first time in our development, we have technologies that can regularly and normally act as autonomous users of other technologies (Floridi, 2014, 30,35).

In his opinion, the problem today is not the extent to which technologies expand human capabilities, but rather the question whether people can function in a world tailored to the needs of machines. In this sense, the human-centric paradigm seems to be an anachronism. Floridi concludes that

our philosophy seems to suggest that 'to be is to be interactable', even if that with which we interact is only transient and virtual (Floridi, 2014, 53).

Finally, it is necessary to highlight the concept of "liquidity" (liquid modernity, liquid life, liquid times) expressed in the work of Bauman (e.g., 2007; 2012). This article has been inspired by his focus on the continuous variability of beings as well as by his conviction that lacking of pre-established, widely accepted principles of functioning, individuals are forced to constantly self-become or even self-create.

\section{Information user}

Although, occasionally, the user was the object of interest in information science before the user-turn,

(...) at this early stage of investigation (that is, up to the early 1970s), there was little in the way of genuine academic or scholarly interest in the subject (Wilson, 2008, 459).

Generally speaking, the user was treated as a client (or a representative of a particular category of clients) of broadly understood information systems - a statistical, abstract entity deprived of the attributes of a real being of any kind (reduced to a label), or as a set of a few selected features revealed in contacts with such systems (Cisek, 2017, 602; Szczechura, 1998, 107-109; Wilson, 2008, 457-458). Within the system-centered paradigm (or intermediary-centered, supply-centered - Savolainen, 1992, 151), the user was typically not investigated as a complex individual equipped with causative power.

The paradigm shift to the user-centered approach (e.g. Aydin, 2017; Savolainen, 1992; Talja \& Hartel, 2007; Vakkari \& Cronin, eds., 1992; Wilson, 1981), which began in the late 1970 s, did not lead to the rejection of the earlier perspective, which remains widely present in empirical studies (Julien, 1999, 207; Julien et al., 2018). Instead, it introduced new approaches, which, generally speaking, (1) focused on information users seen as individual actors, more or less complex entities potentially able to initiate and realize various relations with information as causative agents, and (2) conceptualized information users as human beings (also in social terms). The point of gravity shifted to individual agents (at least in theory) but the question of who or what is such an agent (in the ontological sense) was suppressed by an axiomatic assumption of its human nature.

In the development of the user-centered paradigm over time, one can see a theoretical transition from users seen as rationally directed creatures (a kind of algorithmic "living brains") deliberately choosing optimal solutions and implementing them linearly to flesh 
and blood human beings conditioned by a vast set of diverse stimuli (cognitive, affective, cultural etc.). Step by step, the information user became an increasingly complex human being, sometimes also irrational and emotional - which was even seen as a new affective paradigm in information behavior research (e.g., Cisek, 2017, 602-603; Nahl \& Bilal, eds., 2007; Pettigrew et al., 2001, 46-50). The assumption that the user will consciously choose the shortest and clearly defined way from identification of a need to satisfying it was replaced by the view that the user relies on a variety of strategies, moving back and forth and changing in the course of seeking for information (e.g., Bates, 1989).

Striving to capture the "fullness" of the humanity of information users also led to abandoning an individualistic perspective dominated initially by a cognitive viewpoint (e.g., Belkin, 1990) and focusing on social aspects of their activities. The theory of information science progressed a long way from Belkin's concept of the anomalous state of knowledge (ASK) (Belkin, 1980), through Dervin's sense-making allowing for a collective information agent (Dervin, 1992), a socio-cognitive perspective advocated by Hjørland (2002) and Wilson's interpretation of the activity theory (Wilson, 2006), to what could be termed a "sociological turn" (Cronin, 2008), just to mention the most distinct approaches and concepts. Consequently the information user began to be perceived also as a culturally conditioned member of various communities and society in general (Savolainen, 2016).

Simultaneously, the user gradually began to be seen as a human being "dipped" in various contexts. One can even speak about the crystallization of the context-centered approach (e.g., Tabak, 2014, 2225). Context is understood not only as an external set of diverse stimuli for the users' behavior (a given user may be "transferred" between different contexts remaining itself), but also as a space for social construction of meanings, which integrates users with their surroundings to a greater degree (extracting a user from its context results in a significant transformation of both this user and this context) (Courtright, 2007; Talja et al., 1999). Questions may be asked regarding the extent to which the context is constructed by the user (or vice versa) and the possibility of a clear separation between the user and their context. Dervin's words seem to be significant in this respect: "Context is something you swim in like a fish. You are in it. It is in you" (Dervin, 2003a, 130).

Along with the shifts mentioned above, criticism of positivist and objectivist positions regarding the user opened the possibility for a constructivist, interpretative perspective with its more qualitative, exploratory and ethnographic approach to research. New methodology followed this change. The willingness to study information phenomena and processes through users' eyes resulted in assigning a new role to the user - the creator of the researched reality. In-depth interviews, action research, participant observation and other techniques were employed to investigate these subjective worlds of information users, their motives, assessments, and the shapes they gave to reality (Cisek, 2009; Kuhlthau, 1991; Pickard, 2013; Wilson, 2000).

After all those shifts and extensions of the concept of the information user, it is possible to indicate two key problems in its ontological status in information science. Firstly, the user has been gradually "enriched" with more and more features and determinants (internal and external): this resulted in a situation where a wide range of factors makes their operationalization impossible at the level of empirical research or imposes a priori choices that are difficult to legitimate. This may be a reason for the general negligence of theoretical achievements in designing empirical research and the continued treatment of users as 
one-dimensional clients of information systems or as flat "cartoon characters" animated to perform a specific role. Secondly, in the theory of information science the user is first of all a human, relatively constant in its general nature and as such easily classified according to its selected features. However, the transformations of the information environment and ICT, as well as the development of post-humanist thought and research, make it necessary to rethink the way the information subject (the user) is understood and to accept that agency in information relations does not belong exclusively to people.

\section{General assumptions and related notions}

The starting point for further considerations is to take a step back from the concept of the information user and look for a more general conceptualization that would account for any entity interacting with information. The goal is to avoid preconceptions regarding either its current role (whether it is a user, sender, recipient, creator, etc.) in a particular situation, or its nature (whether it is a human, a software agent or something else). The point is to provide a rudimentary definition to encompass different (preferably all) variants of actual agents appearing in empirically perceived reality. The theoretical framework for thinking about the information agent proposed here is based on the following assumptions about reality and cognition of it.

Firstly, the article takes the relativistic view, assuming that decisions and actions of information agents are shaped by the realities created by these agents, regardless of the extent to which these constructed realities reflect the objective one (assuming that it exists). Any agent interacting with others in information processes is located within its own construct of reality; at the same time, the agent is constructed by other interacting agents - it is what it deems itself to be and what it is deemed by other agents. Relations (negotiations) between interested agents lead to agreement on a common space in which information processes can occur in a way acceptable to all of them.

Secondly, the article assumes that reality is systemic in nature. The term "system" is understood here very broadly as a being consisting of elements connected with each other in such a way that it is able to act as a whole. However, such a whole does not necessarily have to be balanced, stable or fully separable from its environment in an ontological sense. This capacious understanding also includes, for example, networks according to ANT (Callon, 1987, 92-97, 100-101; Law, 1992, 381-384). Furthermore, some components of a system may represent the whole of it in relations with other systems, or, as described in ANT, some subsystems may "speak" on behalf of the whole (Callon, 1986, chapter III.4). A certain component can also obtain hegemony in a system, become its driving force, a center around which the system develops, a place of "high gravity" (like Braudel's cities in the medieval economy system Nowak, 2011, 121-123). To name such a component, the term "formant" will be used.

Thirdly, it was also assumed that reality is dynamic - it is characterized more by becoming than by being. As a consequence, the object of interest here is primarily an event rather than a state. This dynamism (seen also as a "liquidity" (Bauman, 2012)) is understood here as a natural principle of reality, not demanding any goals or reasons. However, this does not necessitate the negation of any intentional actions; rather, it means that goals are not perceived as necessary conditions of actions. 
It is also necessary to introduce at least two related concepts (see also the section 6. Research Opportunities and Methodological Postulates). The first is the concept of an information episode. This is any event (a manifestation of broader information processes) regarding information. The other is the concept of an information situation, which, in accordance with the assumption of the dynamic character of reality, is understood here in terms of a happening. The situation is "the set of things that are happening and the conditions that exist at a particular time and place" (Situation, n.d.); therefore, the information situation is understood here as information agents' activities regarding information and happening in a specific space-time. These concepts require further developments, and are indicated here only to the extent necessary to formulate the concept of the information agent.

\section{Information agent}

\subsection{Information agent as a heterogeneous system}

Despite the humanistic tendencies in information science after the user-turn, it is assumed here that an information agent may not have any human components and can still exist and act. Moreover, even if a human component is a part of a given agent, it does not have to be its formant.

There are several reasons for resigning from anthropocentrism. First of all, today's information environment has already been "populated" by various bots, avatars or software agents. Within the so-called Internet of things (Miller, 2015; Tripathy \& Anuradha, eds., 2018), devices not only generate and send data among themselves but also gain far-reaching autonomy, taking actions independently of the directly expressed human will or knowledge and even replacing humans after their death (Öhman \& Floridi, 2017). In the era of the semantic Web and artificial intelligence, the concept of meaning (so important in information science) also no longer refers only to the state or actions of human minds.

Secondly, a human without ICT tools would not be able to participate in the digital infosphere at all. The limitations and capabilities of such tools determine information agents' activities. For example, communication between agents may depend on the compatibility of devices "representing" them, on the compliance of information encoding formats or transfer protocols. Furthermore, ubiquitous computing (López et al., 2017) and other phenomena result in the generation of so-called big data - which, because of its scale, is impossible for the human mind to analyze. In the inhuman cyberspace, humans appear to be increasingly subordinate to technical entities -

sometimes our ICTs need to understand and interpret what is happening, so they need semantic engines like us to do the job (Floridi, 2014, 146).

Human understanding, relying on a small amount of data and on creating theories based on cause-and-effect relations, begins to be significantly supplemented (or even replaced) by machine-based understanding, reliant on similarities or co-occurrences detected (not necessarily deliberately) in mass data (Chandler, 2015; Kitchin, 2014).

Thirdly, broadly understood posthumanistic thought (the term "posthumanism" is used here as an umbrella term for antihumanism, metahumanism, transhumanism, more 
narrowly defined posthumanism or even ANT) (e.g., Badmington, 2003; Braidotti, 2013; Ferrando, 2013; Kłoda-Staniecko, 2014; Wolfe, 2013) provokes philosophical (i.e. ontological) reflection on relationships between humans and non-humans, and it facilitates a liberation from the automatic attribution of agency to humans alone.

To summarize, the information agent is understood here as a system that can comprise of various components in different proportions. These components can be human beings, things (including devices) and human beings' mental constructs as well as assessments, models or interpretations created by machines, among others. Rejection of anthropocentricism is not synonymous with a negation of the social character of information science. It means accepting entities other than people in the role of individuals in societies (communities). Furthermore, the assumption of the systemic nature of the information agent allows an integration of system-centered and user-centered approaches in information science by resigning from interpreting information situations in terms of human - system relations in favor of system (information agent) - system (information agent) relations.

\subsection{Information agent as a dynamic, multifaced and inseparable being}

The key to understanding the concept of the information agent as proposed here lies in focusing on its life and changes, not on its state. Referring to Bauman's concept of "liquidity" mentioned before, the agent has to constantly self-create, become what it is in a given situation: it is a kind of time-dependent shape-shifter. From the perspective of ANT, the information agent may be seen as a variable (dynamic) densification of the network of relations, which, can stabilize at a particular moment or for a particular period of time, in relation to a particular function or activity (Nowak, 2011, 188, 189). Stability is understood here as the ability to perform a particular function or activity in the same way but not as becoming fixed or petrified. This is not a new idea in information science. The user could change, for example, during the process of seeking a specific piece of information (e.g., Bates, 1989). However, the point here is that such changes do not only concern the cognitive or emotional sphere of a human being acting as the information user; they can mean a transformation of an information agent as a system in terms of its components and the relations between them. In other words, when thinking about a particular information agent (observed in research), one has to set aside aspirations for creating any permanent definition of it. As in ANT, such an agent is a process rather than a being (Law, 1992, 385-386).

In accordance with the assumptions about reality and its cognition, what a particular agent is in a given situation depends not only on its actual components and the relations between them, but also on how it is perceived both by other agents and by itself. While recognizing that at the same time it may reveal a "different face" to different entities (while still having another one for itself) and that its various versions affect relations with other entities in information processes, attention should be paid to the following issues.

Firstly, all such interrelating agents are heterogeneous systems and the way they perceive each other may have the character of human mental constructs (if they contain human components), but this may also be the product of machine perception when technological devices (including software) are parts of these agents. Machine perception may refer to simple technical features and phenomena, when, for example, the goal is to determine the ability of another agent to retrieve data in a specific format. However, it may also mean 
far more advanced interpretations and evaluations of other agents' capabilities, needs or barriers, which can be based on the analysis of mass data regarding their behavior in cyberspace or on the recorded traces of previous contacts (this is what recommender systems do, e.g., Aggarwal, 2016).

Secondly, it is necessary to consider capabilities subjectively attributed to an information agent in a particular situation by itself and by other agents involved in this situation: to see various faces of a particular agent created from various perspectives. The concept of affordances, referred to by Day (2011), understood as an understanding of how to interact with a given agent or as the set of features of a given agent that define its capabilities as seen by itself and by other agents (Fig. 1), is helpful here. Such relative and subjective affordances should be treated as beliefs about an agent's characteristics. As stated above, they do not have to emerge from human minds - they can also be the products of machines as the components of particular agents.

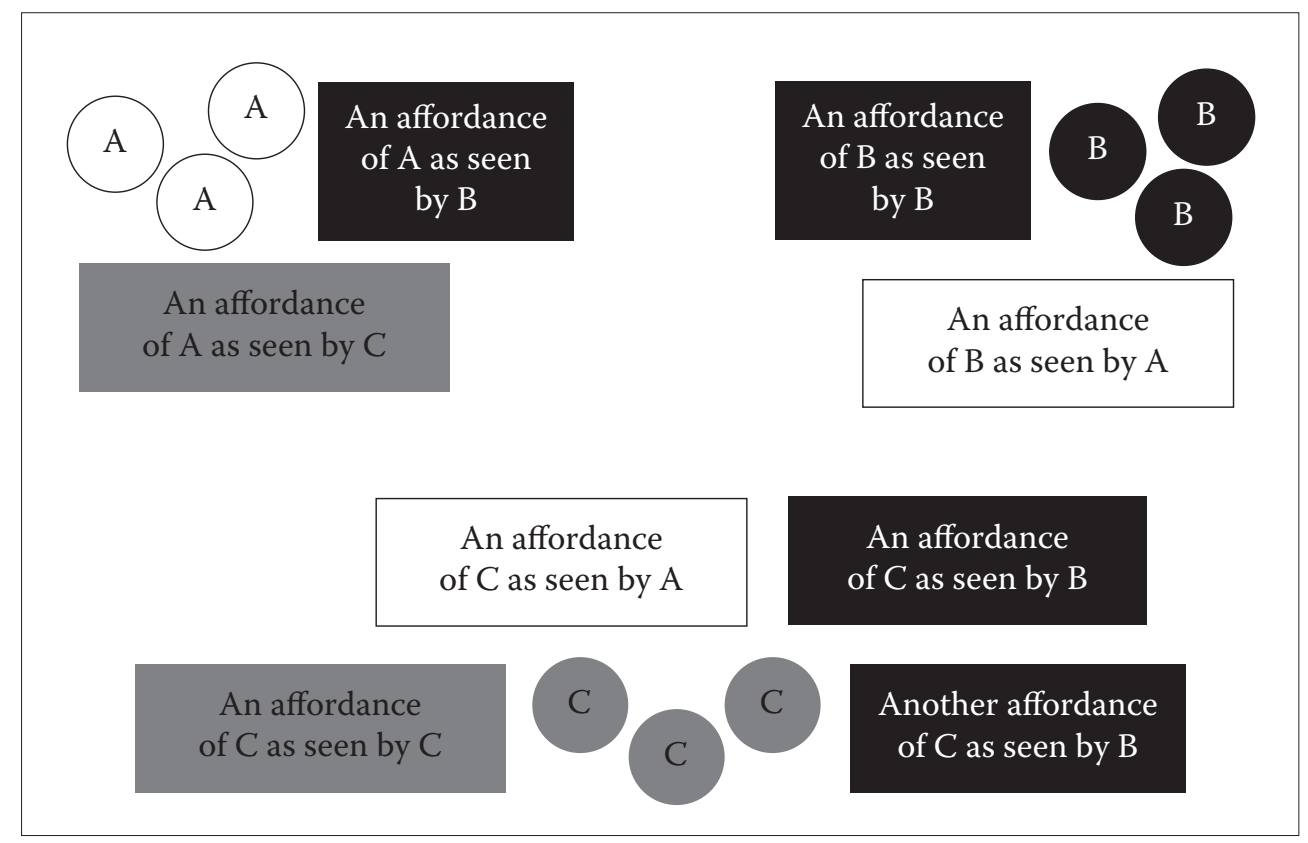

Fig. 1. Multifaced agents and their affordances. An example of hypothetical relations among three information agents $\mathrm{A}, \mathrm{B}$ and $\mathrm{C}$ (circles with the letters inside represent the components of each agent)

Defining the information agent as a densification of the network of relations may result in a possible blurring of its physical separation from the environment. The notion of blurred boundaries between entities is not new - apart from ANT, it was formulated by Braudel (borderland as "no-man's land") $(1995,133)$ among others. Information agents are perceived here as entities that may gradually "fade out", "dissolve" in other entities as the network of relations, which they constitute, becomes less and less dense. Moreover, certain components may be parts of more than one agent, and others may be dedicated 
to establishing and maintaining contacts with other agents (Fig. 2). The scope of such an agent is determined by its agency in particular information situations (see the subsection 5.3. Information Agent as an Agential Being).

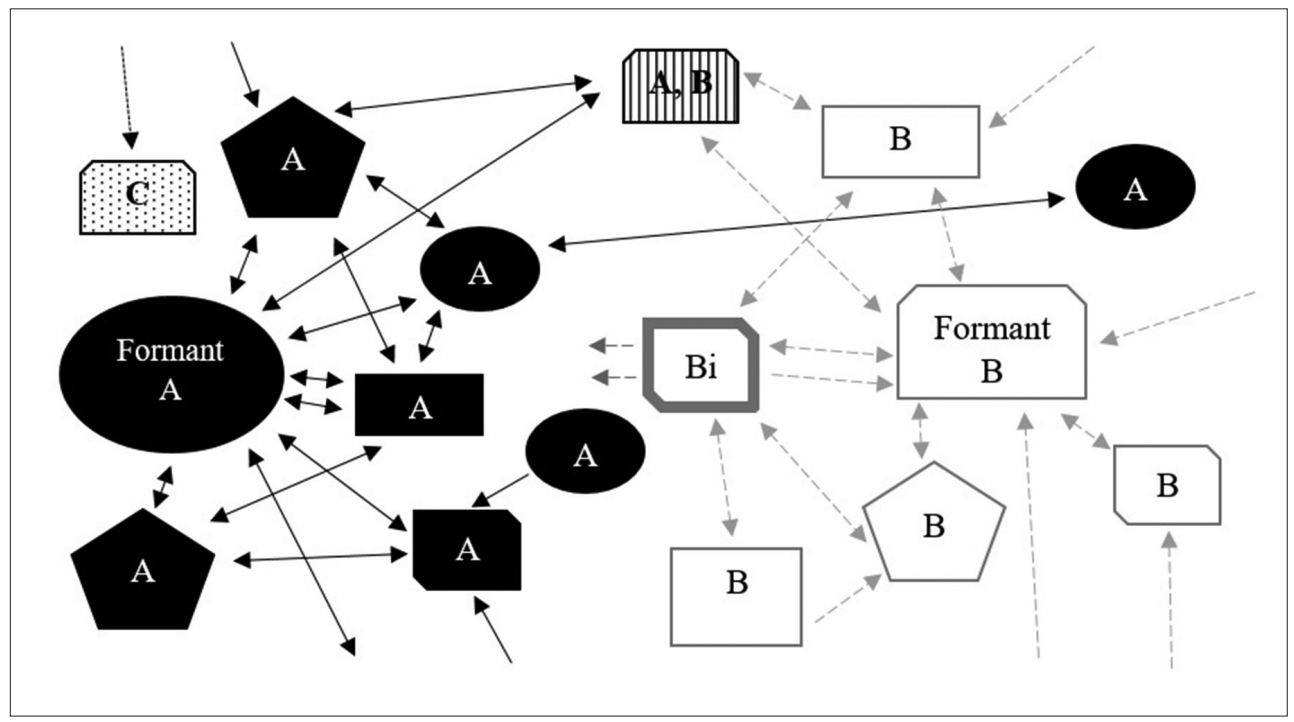

Fig. 2. Information agent in a given situation (A - any component of the agent $A, B$ - any component of the agent $\mathrm{B}, \mathrm{Bi}-$ the component of the agent $\mathrm{B}$ dedicated to connect with the agent $\mathrm{A}$ to carry out a particular information transaction, $\mathrm{C}$ - any component of the agent $\mathrm{C}$; arrows relations between the components)

If something (a device, a cultural factor, a data transfer protocol, etc.) enables or shapes in some way the activities of a given agent in a particular situation, it means that it becomes, at least to some extent, a part of this agent. One can see it as the process of internalizing the new components or loosing those possessed before, which influences the affordances of a particular agent. Referring to Dervin (2003a, 130), thus defined, the information agent is not opposite to its context. It is even not separable from its context, which becomes a part of it or is just not its context (does not influence its behavior in a given situation). Further, it could be argued that the concept of context is unnecessary or can only be defined as a reservoir of potential factors without significance in a particular situation - so weakly related to a given agent that they can be omitted as irrelevant. In other words, instead of an unchanging, stable entity transferable between different contexts, one can see a variable agent that is different in different situations.

\subsection{Information agent as an agential being}

To summarize, it can be said that the information agent is a system consisting of heterogeneous components connected with each other in various ways by dynamic relations, which do not have to be sharply separated from the environment and should not be seen as the opposite to its context, and which may be multiplied and simultaneously exist in 
various versions as constructs created by other agents or by itself. The question is: What makes a particular being an information agent? The answer proposed here is that it is its agency enacted in relation to information. In other words, the information agent is seen as an agential being that directly performs its agency in an information situation (which also means in relation to information processes) which it is involved in - it can, for example, plan, initiate, modify, interrupt or abandon its information related activities.

An entity can become agential (therefore also can become an agent) by, for example, incorporating (internalizing) a new component. This process can be observed in the case of a gunman recalled by Tabak when referring to ANT. Neither the revolver itself, nor the man owning it can shoot anyone (they are only components) - what kills is a gunman, which "is neither a gun nor a man, but a completely new hybrid entity" (Tabak, 2014, 2228).

Agency is not treated here as a permanent attribute of someone or something: it can be obtained, possessed or lost. A particular entity becomes an information agent when it gains agency and ceases to be an agent when it loses agency. In the eyes of some entities, a particular being may be agential in a given information situation and may be treated as an agent, while in the eyes of other entities it may be not, which definitely changes their relations. Thus understood, agency is not determined only by the structure of the entity or the nature of its formant, but it is a result of various factors related to reality and to constructs of it.

\section{Research opportunities and methodological postulates}

How does the framework for thinking about the information agent outlined above broaden research opportunities? Bearing in mind that its real usefulness should be verified in empirical research, the proposals and postulates below should be treated as only initial suggestions for the design of such research.

First of all, this framework may support the development of applied research aimed at improving practical solutions related to particular information situations involving a relatively small number of entities. The potential of this approach seems to be particularly valuable in terms of diagnosing, designing and improving the management of information process at the level of individuals (personal information management), task teams (any forms of collaborative information behavior or group information management), or the relationship between the supplier and the recipient of information which has been traditionally interpreted as relations between people, or between people and broadly understood information systems. It could be used, for example, to identify the causes behind the success or failure of specific agents in given information situations, to identify the ways or conditions for obtaining information agency in specific situations, to assess and improve the efficiency of information transfer between agents or to test technical tools (their use by real agents in practice), and to formulate recommendations for their development.

However, to be able to design such a study, it is necessary to translate this theoretical framework into the operational level of research design. Below are some basic principles that should guide this process.

The main principle is that one should strive to reduce and control apriorisms and simultaneously try to strengthen the heuristic role of research. The point is to consciously 
adopt only the general theoretical framework of the information agent and to aim at identifying real agents and their actions in particular situations through research based on this framework. In other words, one should not assume in advance who or what exactly the actual agents are, as this may lead to the creation of abstract beings and then to their reification when assigning them certain specific, observed behaviors. Research should be focused on what really "works" in a given situation, which affordances (based on the specificity of a given agent's components and their assessment by other agents involved) in fact give agency to a particular entity in the information processes revealed in a particular situation.

The principle of reducing apriorisms forces the researcher to look for a way to start empirical research as soon as possible so that its results can shape the emerging picture of the situation under examination from the very beginning of the whole process of investigation. It is therefore necessary to find a "bridgehead" - a point of entry from which one could begin its exploration. This part could be played by any information episode (defined before), for example: formulating a search query, obtaining a piece of information, deleting a file, etc. An information episode is like one frame from a movie, an "anchor point" from which one can move forward and backward on the timeline to gradually discover the film. Starting from such an episode, one should follow the actions (both the "internal events" within particular agents and their external activities relating to other agents or their components) to discover the agents in the situation they are involved in and their operations. However, one should not rush to determine the causes and effects of this episode, as this could lead to premature overtheorizing of the observation. In relation to the metaphor of the film: the frames preceding one selected as the episode do not necessarily show the reasons for this episode, and the frames following it are not necessarily concerned with its results.

Moreover, because, in accordance with previously taken decisions, information agents reveal themselves only in information situations, and because there are no agents in general (existing irrespective of any situation), it is necessary to propose a method of delimiting information situations under investigation. Generally, a situation should be determined by the scope of the agent (or agents) (which, as previously mentioned, should be defined by its agency in the particular situation) involved in the information processes identified as directly related to a given episode. Such a solution, in connection with specific research objectives, should allow effective practical actions to be taken as a result of applied research or contribute to understanding the activities of information agents and accompanying phenomena in the case of basic research.

Finally, since a rather relativistic and constructivist approach has been adopted here, attention should be paid to how the agents experience the situation they are involved in (all the actions, processes, other agents and their affordances). This requires the use of data collection techniques that give a view of a given information situation through the eyes of its participants. However, the assumption of the dynamics and heterogeneity of agents consisting not necessarily or not only of human components, forces a search for solutions that go beyond various forms of interviews or other human-oriented techniques, and suggests the need to develop new methods to "hear" and observe such agents in action. 


\section{Conclusions}

The theoretical framework for thinking about the information agent proposed here differs from the traditional way of seeing the information user in information science. First of all, instead of assuming (consciously or not) who or what the subject entering into relations with information is or just ignoring this problem and focusing on the behavior of such a "something" in different contexts, the concept proposed here is based on the belief that it is necessary to discover and identify real information agents involved in particular situations by means of empirical research. Instead of preconceiving (basing on theory developments) increasingly numerous and diverse factors that might influence the user's behavior, emphasis is placed on empirical identification of those factors that, as the components of involved agents, actually exert influence on their operations in the researched situations.

Furthermore, the framework proposed here rejects the human-centric perspective and the whole range of explicit and tacit assumptions about the human-user. Unlike the human-user with its special status as a human being, expressed first of all in its "natural" agency and relatively stable, single identity, who operates in different contexts, the information agent is a dynamic and heterogeneous entity gaining agency (therefore, becoming an agent) in specific situations and losing it in others. Referring to the metaphor of the states of matter used by Bauman (2012), while the information user is rather like a solid that can change but is easily definable in space and only slightly sensitive to the passage of time, the information agent is like a liquid that has no specific and constant form of its own that could be used to define it. Such an agent can be composed of various components and at the same time appear in different "incarnations", being perceived differently by other agents. What is more, the information agent is not contrasted with its context but is deemed to be one with it.

According to Savolainen $(1992,160)$, any research paradigm should be not only philosophically well-grounded and methodologically developed, but also tested and matured in empirical research. Even if some basic methodological postulates have been formulated here, there is still a need for further developments to expand the concept presented in this article to shape the information agency paradigm and to make it fully adequate for designing empirical research and for guiding the interpretation of their results.

\section{References}

Abriszewski, K. (2008). Poznanie, zbiorowość, polityka. Analiza teorii aktora-sieci Bruno Latoura. Kraków: Universitas.

Aggarwal, C.C. (2016). Recommender Systems: The Textbook. Cham: Springer.

Aydin, A.M. (2017). Cognition to Collaboration: User-centric Approach and Information Behaviour Theories/Models. Informing Science: The International Journal of an Emerging Transdiscipline, 20, 1-20. https://doi.org/10.28945/3615

Badmington, N. (2003). Theorizing Posthumanism. Cultural Critique, 53, 10-27. https://doi. org/10.1353/cul.2003.0017

Bates, M.J. (1989). The Design of Browsing and Berrypicking Techniques for Online Search Interface. Online Review, 13(5), 407-424. https://doi.org/10.1108/eb024320

Bauman, Z. (2007). Liquid Life. Cambridge: Polity Press.

Bauman, Z. (2012). Liquid Modernity. Cambridge: Polity Press. 
Belkin, N.J. (1980). Anomalous States of Knowledge as a Basis for Information Retrieval. Canadian Journal of Information Science, 5, 133-143.

Belkin, N.J. (1990). The Cognitive Viewpoint in Information Science. Journal of Information Science, 16(1), 11-15. https://doi.org/10.1177/016555159001600104

Booth, A. (2008). In: Search of the Mythical 'Typical Library User'. Health Information \& Libraries Journal, 25(3), 233-236. https://doi.org/10.1111/j.1471-1842.2008.00780.x

Braidotti, R. (2016). The Posthuman. Cambridge: Polity Press.

Braudel, F. (1995). The Mediterranean and the Mediterranean World in the Age of Philip II (Vol. 1). Berkeley, CA: University of California Press.

Callon, M. (1986). Some Elements of a Sociology of Translation: Domestication of the Scallops and the Fishermen of St Brieuc Bay. In: J. Law (ed.). Power, Action and Belief: A New Sociology of Knowledge? (196-233). London: Routledge.

Callon, M. (1987). Society in the Making: The Study of Technology as a Tool for Sociological Analysis. In: W.E. Bijker, T.P. Hughes \& T. Pinch (eds.). The Social Construction of Technological Systems: New Directions in the Sociology and History of Technology (83-103). Cambridge, MA: MIT Press.

Chandler, D. (2015). A World Without Causation: Big Data and the Coming of Age of Posthumanism. Millennium: Journal of International Studies, 43(3), 833-851. https://doi. org $/ 10.1177 / 0305829815576817$

Cisek, S. (2009). Metodologia badań użytkowników informacji w XXI wieku w świetle anglojęzycznej literatury przedmiotu. Praktyka i Teoria Informacji Naukowej $i$ Technicznej, 17(4), 3-11.

Cisek, S. (2017). Użytkownik informacji. W: A. Żbikowska-Migoń \& M. Skalska-Zlat (eds.). Encyklopedia ksiażki (Vol. 2, 602-603). Wrocław: Wydaw. Uniwersytetu Wrocławskiego.

Courtright, C. (2007). Context in Information Behaviour Research. Annual Review of Information Science and Technology, 41(1), 273-306. https://doi.org/10.1002/aris.2007.1440410113

Cronin, B. (2008). The Sociological Turn in Information Science. Journal of Information Science, 34(4), 465-475. https://doi.org/10.1177/0165551508088944

Day, R. E. (2011). Death of the User: Reconceptualizing Subjects, Objects, and Their Relations. Journal of the American Society for Information Science and Technology, 62(1), 78-88. https:// doi.org/10.1002/asi.21422

Dervin, B (1992). From the Mind's Eye of the User: The Sense-Making Qualitative-Quantitative Methodology. In: J.D. Glazier \& R.R. Powell (eds.). Qualitative Research in Information Management (61-84). Englewood, CO: Libraries Unlimited.

Dervin, B. (1999). On Studying Information Seeking and Use Methodologically: The Implication of Connecting Metatheory to Method. Information Processing and Management, 35(6), 727-750. https://doi.org/10.1016/S0306-4573(99)00023-0

Dervin, B. (2003a). Given a Context by Any Other Name: Methodological Tools for Taming the Unruly Beast. In: B. Dervin \& L. Foreman-Wernet (with E. Lauterbach) (eds.). Sense-Making Methodology Reader: Selected Writings of Brenda Dervin (111-132). Cresskill, NJ: Hampton Press.

Dervin, B. (2003b). Human Studies and User Studies: A Call for Methodological Inter-Disciplinarity. Information Research [online], 9(1), paper 166, [10.02.2020], http://www.informationr.net/ir/9-1/paper166.html

Ferrando, F. (2013). Posthumanism, Transhumanism, Antihumanism, Metahumanism, and New Materialisms. Existenz, 8(2), 26-32.

Fleming-May, R.A. (2014). Concept Analysis for Library and Information Science: Exploring Usage. Library and Information Science Research, 36(3/4), 203-210. https://doi.org/10.1016/j.lisr.2014.05.001

Floridi, L. (2014). The 4th Revolution: How the Infosphere Is Reshaping Human Reality. New York, NY: Oxford University Press.

Hjørland, B. (2002). Epistemology and the Socio-Cognitive Perspective in Information Science. Journal of the American Society for Information Science and Technology, 53(4), 257-270. https:// doi.org/10.1002/asi.10042 
Julien, H. (1999). Constructing "Users" in Library and Information Science. Aslib Proceedings, 51(6), 206-209. https://doi.org/10.1108/EUM0000000006979

Julien, H., McKechnie, L., Polkinghorne, S., Chabot, R. (2018). The "User Turn" in Practice: Information Behaviour Researchers' Constructions of Information Users. In: Proceedings of ISIC: The Information Behaviour Conference, Kraków, Poland, 9-11 October, 2018 (Part 1). Information Research [online], 23(4), paper isic1804, [10.02.2020], http://www.informationr.net/ir/23-4/isic2018/ isic1804.html

Kitchin, R. (2014). Big Data, New Epistemologies and Paradigm Shifts. Big Data E Society. https:// doi.org/10.1177/2053951714528481

Kłoda-Staniecko, B. (2014). Ja, cyborg. Trzy porządki, jeden byt. Podmiot jako fuzja biologii, kultury i technologii. W: J. Tymieniecka-Suchanek (red.). Człowiek w relacji do zwierząt, roślin i maszyn w kulturze: Vol 1. Aspekt posthumanistyczny i transhumanistyczny (362-371). Katowice: Wydaw. Uniwersytetu Śląskiego.

Kuhlthau, C.C. (1991). Inside the Search Process: Information Seeking from the User's Perspective. Journal of the American Society for Information Science, 42(5), 361-371. https://doi.org/10.1002/ (SICI)1097-4571(199106)42:5<361::AID-ASI6>3.0.CO;2-\%23

Latour, B. (1996). On Actor-Network Theory. A Few Clarifications Plus More Than a Few Complications. Soziale Welt, 47, 369-381.

Law, J. (1992). Notes on the Theory of the Actor Network: Ordering, Strategy and Heterogeneity. Systemic Practice and Action Research, 5(4), 379-393. https://doi.org/10.1007/BF01059830

Law, J., Hassard, J. (1999). Actor Network Theory and After. Oxford: Blackwell Publishers.

López, G., Marín, G., Calderón, M. (2017). Human Aspects of Ubiquitous Computing: A Study Addressing Willingness to Use It and Privacy Issues. Journal of Ambient Intelligence and Humanized Computing, 8(4), 497-511. https://doi.org/10.1007/s12652-016-0438-4

McKechnie, L.E.F., Julien, H., Pecoskie, J.L., Dixon, C.M. (2006). The Presentation of the Information User in Reports of Information Behaviour Research. Information Research [online], 12(1), paper 278, [10.02.2020], http://www.informationr.net/ir/12-1/paper278.html

Miksa, F. (2009). Information Organization and the Mysterious Information User. Libraries \& the Cultural Record, 44(3), 343-372. https://doi.org/ 10.1353/lac.0.0075

Miller, M. (2015). The Internet of Things: How Smart TVs, Smart Cars, Smart Homes, and Smart Cities are Changing the World. Indianapolis, IN: Que.

Nahl, D., Bilal, D. (eds.) (2007). Information and Emotion: The Emergent Affective Paradigm in Information Behaviour Research and Theory. Medford, NJ: Information Today.

Nowak, A.W. (2011). Podmiot, system, nowoczesność. Poznań: Wydawnictwo Naukowe Instytutu Filozofii UAM w Poznaniu.

Olsson, M.R. (2016). Re-Thinking Our Concept of Users (reprint). Australian Academic E Research Libraries, 47(4), 286-299, https://doi.org/10.1080/00048623.2016.1253426

Öhman, C., Floridi, L. (2017). The Political Economy of Death in the Age of Information: A Critical Approach to the Digital Afterlife Industry. Minds and Machines, 27(4), 639-662. https://doi. org/10.1007/s11023-017-9445-2

Pettigrew, K.E., Fidel, R., Bruce, H. (2001). Conceptual Frameworks in Information Behavior. Annual Review of Information Science and Technology, 35, 43-78.

Pickard, A.J. (2013). Research Methods in Information. Second Edition. London: Facet Publishing.

Savolainen, R. (1992). The Sense-Making Theory - an Alternative to Intermediary-Centred Approaches in Library and Information Science? In: P. Vakkari \& B. Cronin (eds.). Conceptions of Library and Information Science: Historical, Empirical and Theoretical Perspectives (149-164). London: Taylor Graham.

Savolainen, R. (2016). Approaches to Socio-Cultural Barriers to Information Seeking. Library \& Information Science Research, 38(1), 52-59. https://doi.org/10.1016/j.lisr.2016.01.007 
Situation (n.d.). Cambridge Dictionary [online], [10.02.2020], https://dictionary.cambridge.org/ dictionary/english/situation

Szczechura, K. (1998). Użytkownicy informacji. Zarys problematyki. W: E. Ścibor (ed.). Informacja naukowa w Polsce. Tradycja i wspótczesność (107-138). Olsztyn: Wydaw. WSP.

Tabak, E. (2014). Jumping Between Context and Users: A Difficulty in Tracing Information Practices. Journal of the Association for Information Science and Technology, 65(11), 2223-2232. https://doi. org/10.1002/asi.23116

Talja, S. (1997). Constituting "Information" and "User" as Research Objects: A Theory of Knowledge Formations as an Alternative to the Information Man-Theory. In: P. Vakkari, R. Savolainen \& B. Dervin (eds.). Information Seeking in Context (81-96). London: Taylor Graham.

Talja, S., Hartel, J. (2007). Revisiting the User-Centered Turn in Information Science Research: An Intellectual History Perspective. Information Research [online], 12(4), paper colis04, [10.02.2020], http://www.informationr.net/ir/12-4/colis/colis04.html

Talja, S., Keso, H., Pietiläinen, T. (1999). The Production of "Context" in Information Seeking Research: A Metatheoretical View. Information Processing \& Management, 35(6), 751-763. https:// doi.org/10.1016/S0306-4573(99)00024-2

Tripathy, B.K., Anuradha, J. (eds.) (2018). Internet of Things (IoT): Technologies, Applications, Challenges and Solutions. Boca Raton, FL: Taylor \& Francis, CRC Press.

Vakkari, P., Cronin, B. (eds.) (1992). Conceptions of Library and Information Science: Historical, Empirical and Theoretical Perspectives. London: Taylor Graham.

Wilson, T.D. (1981). On User Studies and Information Needs. Journal of Documentation, 37(1), 3-15. https://doi.org/10.1108/eb026702

Wilson, T.D. (2000). Recent Trends in User Studies: Action Research and Qualitative Methods. Information Research [online], 5(3), paper 76, [10.02.2020], http://www.informationr.net/ir/5-3/ paper76.html

Wilson, T.D. (2006). A Re-Examination of Information Seeking Behaviour in the Context of Activity Theory. Information Research [oline], 11(4), paper 260, [10.02.2020], http://www.informationr. net/ir/11-4/paper260.html

Wilson, T.D. (2008). The Information User: Past, Present and Future. Journal of Information Science, 34(4), 457-464. https://doi.org/10.1177/0165551508091309

Wolfe, C. (2013). What is Posthumanism. Minneapolis, MN: University of Minnesota Press.

\title{
Czym jest agent informacyjny? W poszukiwaniu nowego podejścia do podmiotu procesów informacyjnych
}

\begin{abstract}
Abstrakt
Cel/Teza: Artykuł proponuje poszerzenie możliwości badawczych poprzez wyjście poza koncepcję użytkownika informacji i rozwijanie paradygmatu badawczego opartego na koncepcji sprawczości informacyjnej. Szczegółowym celem jest stworzenie teoretycznych ram dla nowego sposobu myślenia o podmiocie procesów informacyjnych.

Koncepcja/Metody badań: Artykuł ma charakter koncepcyjny i został oparty na rozważaniach teoretycznych oraz na syntetycznych, krytycznych analizach zarówno koncepcji użytkownika informacji, jak i innych, wybranych koncepcjach leżących u podstaw proponowanego tutaj podejścia. Wyniki i wnioski: Zaproponowano teoretyczne ramy koncepcji agenta informacyjnego, który jest postrzegany jako dynamiczny, heterogeniczny, wielopłaszczyznowy i nierozerwalny system, który zyskuje sprawczość w określonych sytuacjach i traci ją w innych.
\end{abstract}


Oryginalność/Wartość poznawcza: Przedstawiono oryginalną koncepcję agenta informacyjnego wraz z wstępnymi sugestiami dotyczącymi jej zastosowań i sposobu operacjonalizacji na poziomie projektowania badań empirycznych.

\section{Słowa kluczowe}

Agent informacyjny. Metodologia. Podmiot procesów informacyjnych. Sprawczość informacyjna.

Teoria badań informacyjnych. Użytkownik informacji.

REMIGIUSZ SAPA, PhD, habil. is Associate Professor in the Institute of Information Studies of the Jagiellonian University in Kraków, Poland. Scientific interests: individual and group information management, information behavior, theory and methodology of information research, diagnostics of information systems and academic librarianship. Selected latest publications: Sapa, R. (ed.) (2017). Diagnostyka w zarządzaniu informacją: perspektywa informatologiczna. Kraków, Poland: Jagiellonian Library; Sapa, R. (2019). Indywidualne zarzadzanie informacja. In: W. Babik (ed.), Zarządzanie informacją (127-153). Warsaw, Poland: SBP.

Contact to the Author:

remigiusz.sapa@uj.edu.pl

Institute of Information Studies

Faculty of Management and Social Communication

Jagiellonian University in Kraków

prof. Stanistawa Łojasiewicza 4

30-348 Kraków, Poland 